\title{
ON MANNIA ANDROGYNA (AYTONIACEAE, MARCHANTIOPHYTA) IN EASTERN ASIA
}

\author{
Eugene A. Borovichev ${ }^{1}$, Vadim A. Bakalin \& Masanobu Higuchi
}

\begin{abstract}
The discovery of Mannia androgyna (L.) A. Evans in Russian Asian and Japanese localities changes the conception of the distribution patterns of the taxon, previously regarded as principally a Mediterranean species. A description and illustrations based on specimens collected in Russian Asia and Japan are provided. The history of the taxonomic understanding of Mannia androgyna is briefly reviewed, and features differentiating closely related species are discussed.
\end{abstract}

Key words: Aytoniaceae, distribution, Hepatics, phytogeography, taxonomy

Eugene A. Borovichev, Polar-Alpine Botanical Garden-Institute of the Kola Science Center of RAS, Kirovsk, Murmansk Province, 184256, Russia; Institute of Industrial Ecology Problems of the North of the Kola Science Center of RAS, Apatity, Murmansk Province, 184209, Russia; e-mail: borovichyok@mail.ru

Vadim A. Bakalin, Botanical Garden-Institute FEB RAS, Makovskogo Street, 142, Vladivostok, 690024, Russia; Institute of Biology and Soil Science FEB RAS, Stoletiya Vladivostoka Avenue, 159, Vladivostok, 690022, Russia; e-mail: v_bak@list.ru Masanobu Higuchi, Department of Botany, National Museum of Nature and Science, 4-1-1 Amakubo, Tsukuba, Ibaraki 305-0005, Japan; e-mail: higuchi@kahaku.go.jp

\section{INTRODUCTION}

Mannia androgyna (L.) A. Evans has been regarded as a Mediterranean hepatic distributed mainly in Southern Europe (Schumacker \& Váňa 2005) and North Africa (Wigginton 2004), although disjunctively occurring eastward to the Arabian Peninsula (Kürschner et al. 2001) and as far as the Indian subcontinent (Singh \& Singh 2009). Recently it was found in the Russian Far East (Borovichev \& Bakalin 2013b). In addition to the latter record, the first author later revealed the species in the Altay Republic, Chelyabinsk and Sakhalin Provinces (Russian Asia) and Saitama Prefecture (Japan). These records confirm a distribution of the taxon wider than previously known.

This paper lists new localities for the species and discusses its distribution pattern in light of the new data presented, and provides a description of Mannia androgyna based on available specimens from the area studied.

\footnotetext{
1 Corresponding author
}

\section{HISTORICAL TAXONOMIC BACKGROUND}

Raddi (1818) described the genus Grimaldia based on the single species $G$. dichotoma Raddi. Unfortunately the generic name proved to be an illegitimate later homonym of the name used for vascular plants Grimaldia Schrank published in 1805 [now generally treated as Chamaecrista sect. Grimaldia (Schrank) H. S. Irwin \& Barneby]. Overlooking that evidence, Corda (1829) in Opiz's Beiträge zur Naturgeschichte accepted the genus Grimaldia Raddi with two species, G. raddii Corda and G. michelii Corda (both names being illegitimate - see below), but Opiz, the editor of the book, noticed the priority of Grimaldia Schrank and proposed to replace Grimaldia Raddi for Mannia (in honor of Dr. Wenzeslaus B. Mann). Nevertheless, Grimaldia sensu Raddi was used for a long time until the middle of the $20^{\text {th }}$ century (Gottsche et al. 1844-1847; Leitgeb 1881; Schiffner 1893, 1908; Stephani 1898-1924; Müller 1954). In 1934 the generic name Mannia was restored to the literature by Wheeler (1934) and then used by Frye and 
Clark (1937), Evans (1938), Schuster (1953, 1992) and others. Evans (1938) stressed that the name Mannia must be accredited to Opiz rather than to Corda (the same with the combinations $M$. raddi and M. michelii).

Only Müller (1954) refrained from the usage of Mannia in favor of Grimaldia Raddi. He stated that Marchantia androgyna L. is distinct from Grimaldia dichotoma Raddi. The decision was connected with the fact that $G$. dichotoma is based on two different elements: Marchantia triandra Scop. (Scopoli 1772) and Micheli's polynomial Hepatica minor, angustifolia, capitulo hemisphaerico (Micheli 1729).

After the name Mannia had been widely accepted, another generic name for this taxon was found: Cyathophora Gray, validly published in 1821, with the single species $C$. angustifolia (Gray 1821). Since Cyathophora is earlier than Mannia it ought to be adopted formally. However, to avoid further nomenclatural changes, Grolle (1981, 1983b, c) proposed to conserve Mannia Opiz against Cyathophora Gray, and the Committee for Bryophyta accepted his proposal in 1988 (Ziljstra 1989).

Publishing his Grimaldia dichotoma, Raddi (1818) cited the earlier and validly published name Marchantia triandra Scop. (Scopoli 1772) in its synonymy. So, in addition to having an illegitimate generic name, Grimaldia dichotoma Raddi is a superfluous name [see ICN, Art. 52.1 and 52.2(e)]. Likewise, the names Grimaldia raddii Corda (= Mannia raddii Opiz) and Grimaldia michelii Corda (= Mannia michelii Opiz) are superfluous, since Grimaldia dichotoma Raddi (and therefore Marchantia triandra Scop.) is cited as a synonym of the former, and Marchantia angustifolia Neck. as a synonym of the latter. In fact, Marchantia angustifolia Neck. is also a superfluous name, because its synonymy completely repeats that of Marchantia androgyna L. Similarly, Marchantia androgyna is cited in the synonymy of Cyathophora angustifolia Gray, to make the latter superfluous as well. The earliest legitimate name of the discussed taxon at the rank of species is Marchantia androgyna L., so its epithet ought to be used to make the correct combination. This was done by Evans (1938), who published Mannia androgyna (L.) A. Evans.

Arnell (1961a) proposed the new combination Mannia dichotoma (Raddi) S. W. Arnell. Later, Udar and Chandra (1965), overlooking Arnell's valid combination (Arnell 1961a), cited his later paper (Arnell 1961b) where this name was only mentioned, and regarded Arnell's combination as 'comb. nudum'. As the result they created a superfluous combination: Mannia dichotoma (Raddi) Udar \& Chandra. In addition, they cited Marchantia androgyna as a synonym of the name.

Grolle (1968) found Mannia androgyna and Micheli's polynomial Hepatica minor, angustifolia, capitulo hemisphaerico formally lectotypified by Marchantia androgyna L. Later Grolle suggested that the name Grimaldia dichotoma was a synonym of the name Mannia triandra and therefore proposed to consider the latter as lectotype, basing on Scopoli's specimen. That would make Mannia triandra a type of genus (Grolle 1975, 1983a, b). However, the ICBN Nomenclature Committee for Bryophyta (Ziljstra 1990) rejected Grolle's proposal and chose Micheli's polynomial (as the older one) as lectotype of $G$. dichotoma. Therefore the Linnaean name Marchantia androgyna has priority over Grimaldia dichotoma; Mannia angrogyna is the type species of both Mannia and Grimaldia Raddi; the lectotype of Mannia androgyna is the same as the lectotype of Grimaldia dichotoma, and the combination proposed by Evans (1938) as Mannia androgyna is correct.

Mannia androgyna (L.) A. Evans Figs 1 \& 2

Chron. Bot. 4: 225. 1938. - Marchantia androgyna L., Sp. P1.: 1138. 1753. - Grimaldia dichotoma Raddi, Opusc. Sci. (Bologna) 2: 356. 1818. - Mannia dichotoma (Raddi) S. W. Arnell, Bot. Not. 114: 179. 1961; idem, Svensk Bot. Tidskr. 55: 382. 1961b. nom. inval. - Mannia dichotoma (Raddi) Udar \& Chandra, Canad. J. Bot. 43: 153. 1965. nom. inval. - Grimaldia raddii Corda in Opiz, Beitr. Naturgesch. 12: 646. 1829. Mannia raddii (Corda) Opiz, Beitr. Naturgesch. 12: 646. 1829. - Grimaldia michelii Corda in Opiz, Beitr. Naturgesch. 12: 646. 1829. - Mannia michelii (Corda) Opiz, Beitr. Naturgesch. 12: 646. 1829. - Marchantia angustifolia Neck., Method. Musc.: 117. 1771. - Cyathophora angustifolia S. F. Gray, Nat. Arr. Brit. Pl. 1: 683. 

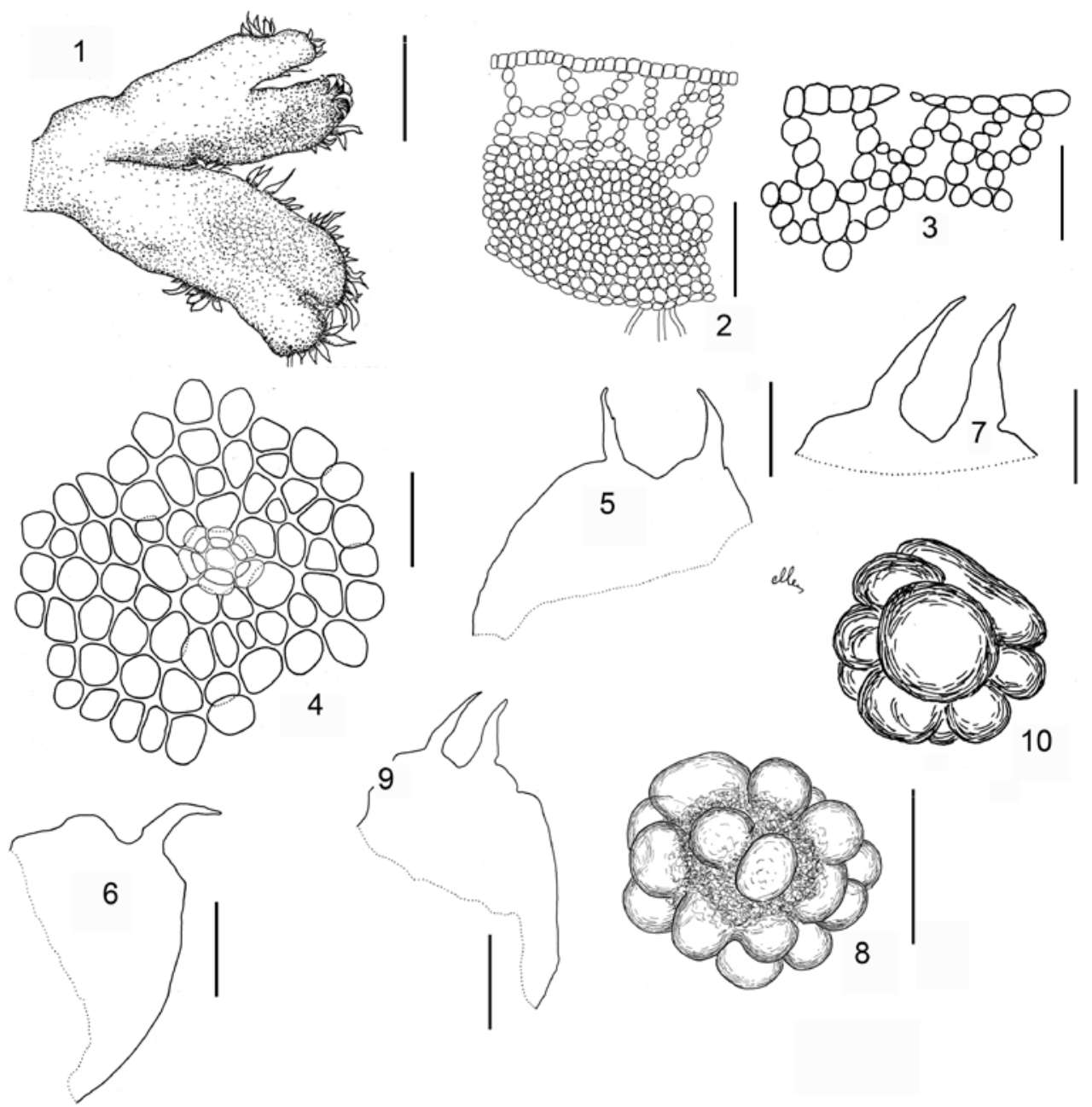

Fig. 1. Mannia androgyna (L.) A. Evans: 1 - habit of sterile plant, dorsal view; 2 \& 3 - part of transverse section with airpore; 4 - air-pore from dorsal epidermis of thallus; 5, $6 \& 9$ - ventral scales with appendages; 7 - appendages of ventral scale; $8 \& 10$ - distal face of spores. 1-7 \& 9 - from Sakhalin Province, 23 July 2010, Barckalov (VBGI); 8 \& 10 - from Altay Republic, 29 July1991, Ignatov \& Ignatova, (MHA). Scale bars: $1=3 \mathrm{~mm} ; 5-7 \& 9=600 \mu \mathrm{m} ; 2 \& 3=300 \mu \mathrm{m} ; 4,8 \& 10=60 \mu \mathrm{m}$.

1821. - Duvalia angustifolia Lindb., Not. Sällsk. Faun. Fl. Fenn. 9: 285. 1868. - Grimaldia androgyna Lindb. Hep. Utveckl.: 26. 1877. - Grimaldia capensis Steph., Sp. Hepat. 1: 90. 1898. - Mannia capensis (Steph.) S. W. Arnell, Mitt. Bot. Staatssamml. München 16: 263. 1957. - Mannia capensis var. pallida S.W. Arnell, Hep. S. Africa.: 72. 1963.

ILLUSTRATIONS: Müller (1954: 345, fig. 62; 346, fig. 63 as Grimaldia dichotoma); Perold (1994: 10, fig. 1; 11, fig. 2 as Mannia capensis); Schill (2006: 111, fig. 4.2; 112, fig. 4.3); Casas et al. (2009: 31, fig. 3: 4-5);
Frahm (2010: 25). MAP: Müller (1954: 343, fig. 61 as Grimaldia dichotoma); Schill (2006: 113, fig. 4.33).

Thalli thick, strongly xeric habit, not fragrant, small, lobes (4-)5-12(-14) $\mathrm{mm}$ long, 1-3 mm wide, forming extensive, \pm pure patches, very sparingly dichotomously branched, frequently with both ventral and terminal innovations; segments linear-lingulate to oblong, rather leathery; apex rounded, ventral scale appendages mainly overlapping lobe apex; upper surface smooth, slightly 


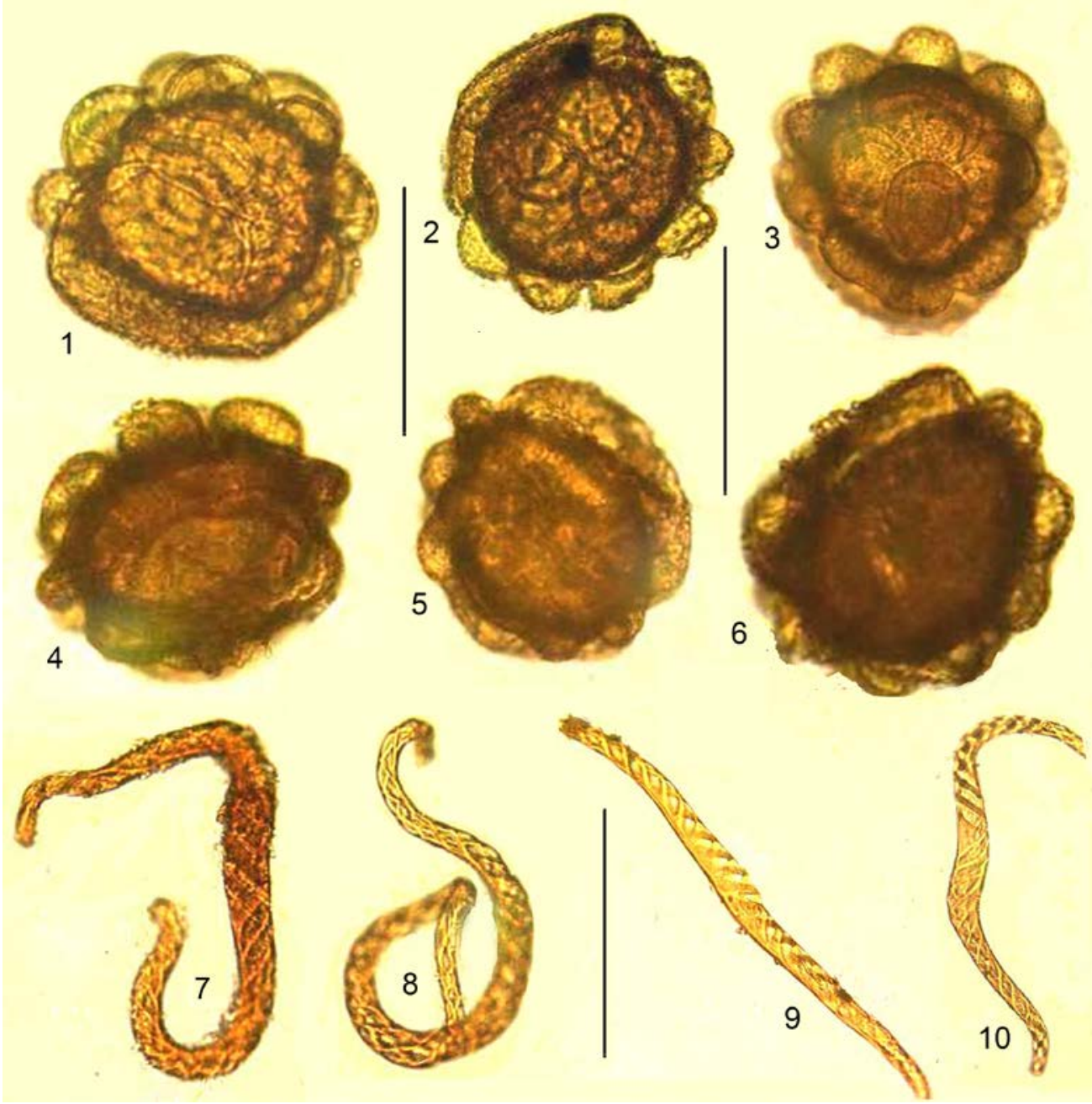

Fig. 2. Mannia androgyna (L.) A. Evans: 1-3, 5 \& 6 - distal face of spores; 4 - proximal face of spore; 7-10 - elaters. Scale bars: $1-6=50 \mu \mathrm{m} ; 7-10=70 \mu \mathrm{m} .1-3 \&$ 7-9 from Altay Republic, Ignatov \& Ignatova, 29 July 1991 (MHA); 4-6 \& 10 from Japan, Inoue, 6 July 1957 (TNS).

concave, not reticulate, pores visible with hand lens as whitish points, brownish or whitish lacunose when disintegrating, color of upper surface green, in older parts becoming brownish; thallus margins dark purple to slightly purple, slightly undulate, when dry slightly to strongly inrolled, tubular and black or not strongly inrolled. Dorsal epidermis delicate to firm, mostly colorless to rose-tinged; cells $12-18-(-20) \times(15-) 20-30 \mu \mathrm{m}$, with thin to slightly thickened walls and distinct trigones; pores simple, only slightly elevated above epidermis, $15-28 \mu \mathrm{m}$ in diameter, surrounded by $2-3$ concentric rings of $(5-) 6-7(-8)$ cells in each, cell walls thin or slightly thickened. Aerenchyma compact, occupying $c a 1 / 3-1 / 2$ of thallus height in the middle; air chambers small, rounded to subisodiametric, 2-3-layered with few free secondary filaments or without them; ventral tissue occupying $c a$ 2/3-1/2 of thallus height in the middle and absent in the wing, parenchymatous, consisting of thin-walled cells; oil-bodies lacking or present, pale-grayish in both aerenchyma and ventral tissue. 
Midrib thallus segment 340-650 $\mu \mathrm{m}$ thick in cross section, \pm well-defined. Rhizoids smooth and pegged, hyaline to purplish towards base, covering ventral surface of midrib of thallus. Ventral scales purple to reddish with sometimes pale purple margins, in two rows on each side of midrib, semicircular to broad-semicircular or lunate, sometimes with a few slime-papillae on margin; body size (500-)600-1200 $\mu \mathrm{m}$ long and (250-)350-900 $\mu \mathrm{m}$ wide; appendages two, subulate, hyaline or reddish, margins irregularly serrate or irregularly weakly crenulate, 150-600(-700) $\mu \mathrm{m}$ long and (80-)100-300 $\mu \mathrm{m}$ wide; appendage apex long- to shortly acute to acuminate; oil bodies numerous, $10-25 \mu \mathrm{m}$ in diameter, present in both body and appendages. Sexual condition usually paroicous or terminal-autoicous, occasionally female-ventral autoicous. Anteridia situated on main thallus on other dichotomous bearing a female receptacle or equally long branch of a dichotomy bearing an archegoniophore (terminal-autoicous) or arising dorsally on leading thallus behind female receptacle (paroicous), but sometimes on main thallus with archegoniophore on shorter ventral branch (female-ventral autoicous); androecial papillae in clusters or loosely dispersed, conspicuous, purplish. Gynoecia in apical notch of terminal branches of thallus or borne on shorter ventral branches; stalk of receptacle brownish green, frequently brownish at base or below receptacle, 10-15 mm long, with single rhizoidal furrow. Archegonial scales hyaline to whitish, irregularly triangular-ovate or rounded. Carpocephalum hemispherical, yellowish green when young, mature turning green and often purple at margins; disc convex, 3-4-lobed, each involucre with single sporophyte; involucre margin membranous; pseudoperianth lacking. Capsule large, globose, with single-layered walls; without thickenings. Spores yellow-brown to brownish, globose, 45-70 $\mu \mathrm{m}$ in diameter, distal face distinctly saccate, bearing very conspicuous hemispherical papillae, mostly separated from each other, with distinct, large hemispherical exosporial cup on proximal face. Elaters yellowish brown to strawcolored, 100-210 $\mathrm{mm}$ long, 8.0-9.5 $\mathrm{mm}$ width at middle, trispiral.

\section{DIFFERENTIATION AND VARIATION}

Mannia androgyna is characterized by pale-grayish oil-bodies in both the aerenchyma and basal tissue, the presence of paroicous- or terminal-autoicous-, rarely female-ventral autoicous inflorescences, and saccate spores with a conspicuous proximal disc. Mannia androgyna appears to be most similar to $M$. californica and $M$. fragrans. It differs from $M$. fragrans in the following characters: $(i)$ never aromatic when fresh, in contrast to the commonly aromatic (cedar-oil) smell of $M$. fragrans; (ii) dorsal surface green with pores visible with a hand lens as whitish points rather than dorsally bright or dark green, sometimes purplish without visible pores; (iii) even in female branches, small, deep purplish scales not forming a dense cluster at the thallus apex, unlike the bleached appendages of scales commonly forming a conspicuous cluster at the apex in $M$. fragrans, especially noticeable in female branches; and (iv) antheridia in loosely or densely aggregated clusters, vs. antheridia forming a slightly upraised disc in $M$. fragrans. Mannia androgyna and $M$. californica are more similar morphologically and can be confused. Mannia androgyna may be distinguished from $M$. californica by the following characters: (i) $M$. androgyna has pale grayish oil-bodies in both the aerenchyma and basal tissue, vs. dark blackish oil-bodies in M. californica; (ii) generally paroicous or terminalautoicous inflorescences, vs. female-ventral autoicous in M. californica; and (iii) saccate spores, vs. alveolate in $M$. californica.

Most authors state that $M$. androgyna is usually paroicous (anteridia arising dorsally on leading thallus behind female receptacle - called terminal-autoicous by Schill 2006) or terminalautoicous (anteridia situated on other branches of main thallus bearing a female receptacle or an equally long branch of a dichotomy bearing an archegoniophore), rarely female-ventral autoicous (female gametangia occur on ventral side branches). In contrast, $M$. californica is characterized by a uniformly autoicous inflorescence with gynoecia located on the ventral branches (e.g., Stephani 1898-1924; Huggonot \& Schill 2006; Schill et al. 2008). Studies of abundant material 
from Japan revealed that the species is able to bear both ventral and terminal autoicous inflorescences, but the latter is more common. Sometimes early-decaying thallus bases give the appearance of being dioicous, but careful examination always shows that the male and female branches originally were united in a single thallus. Similar cases of pseudodioicous inflorescences were described in Sauteria alpina (Nees) Nees (Cleveaceae) (Schuster 1992; Borovichev et al. 2012).

ECOLOGY. In respect of its ecology, Mannia androgyna is broadly similar to Mannia fragrans (Balb.) Frye \& L. Clark, tending to occupy dry or rarely wet soil-filled crevices in rock outcrops and cliffs at open sites. The majority of records from the studied area are from coastal cliffs or open cliffs along watercourses but avoiding direct exposure to running water. Sometimes the species occurs on dry slopes under semi-xeric shrubs such as Caragana spp. and Lespedeza spp., as well as in discontinuous low grass communities on steep slopes to sea coasts, lakes and rivers (away from direct contact with water). Other species with which Mannia androgyna sometimes grows include Reboulia hemisphaerica (L.) Raddi and Targionia hypophylla L.

Distribution. The species has a generally Mediterranean-circum-Tethian distribution, though also occurring in central Japan in areas with more or less xeric conditions. In Europe the distribution area covers Portugal (including the Azores, Madeira and Canary Islands), Italy (including Sardinia and Sicily), Spain (including the Balearic Islands), Greece (including Crete), Serbia, Bulgaria, Croatia, Montenegro, Turkey, Bosnia and Herzegovina, Albania, France (including Corsica), Austria, Switzerland (Söderström et al. 2002; Schumacker \& Váňa 2005; Schill 2006) and Ukraine (Borovichev \& Nyporko 2014). In Africa the species has been reported from Morocco, Algeria, Chad, the Cape Verde Islands, Eritrea, Ethiopia and the island of Socotra (Wigginton 2004). Eastward, M. androgyna spreads to the Arabian Peninsula (United Arab Emirates: Kürschner et al. 2001) and the Indian Subcontinent (Pakistan, as Asterella calciatii (Gola) Kachroo
\& Bapna: Long 2006; Himalayan India: Singh \& Singh 2009). Within Russia the species was reported from the North Caucasus in the Republic of Adygeya (Konstantinova et al. 2009) and is also found in the Russian Far East: Primorsky Territory and Amurskaya Province (Borovichev \& Bakalin 2013b). There is also a record by Brotherus (1892) from 'Osetia, Lars \& Kobi ad fl. Terek' that probably relates to North Ossetia (currently a republic within Russia) or to South Ossetia. The present account provides additional data on the distribution of the taxon in the Altay Republic (South Siberia), Chelyabinsk Province and Sakhalin Province. Eastward of Russia we recorded this species from Japan in Ohtaki-mura, Chichibu Mts.

SPECIMENS OF MANNIA ANDROGYNA EXAMINED (newly reported areas asterisked): RUSSIA. *ALTAY REPUBLIC, Altay State Nature Reserve, Schebalino District, Katun River Valley near Ust'-Sema, $\sim 51^{\circ} 40^{\prime} \mathrm{N}$, $85^{\circ} 52^{\prime} \mathrm{E}, 580 \mathrm{~m}$ alt., rather dry slope, on soil rich in humus, in shade of Caragana shrubs, with sporogonium, 29 July 1991, M.S. Ignatov \& E.A. Ignatova s.n. (MHA); ibidem, rock outcrops near Katun bank, 28 July 1991, M.S. Ignatov \& E.A. Ignatova s.n. (MHA); ibidem, eastern shore of Teletzkoe Lake, Chiri, xeric S-facing rocky slope, $\sim 51^{\circ} 22^{\prime} \mathrm{N}, 87^{\circ} 50^{\prime} \mathrm{E}, 450 \mathrm{~m}$ alt., on dry soil among rocks, 19 July 1991, M.S. Ignatov s.n. (MHA); *Chelyabinskaya Province, Zyuratkyul' National Park, Malyj Moskal' Range, 5454'41.7"N, 5909'15.4"E, limestone cliffs along road, on soil, 22 May 2009, I.N. Urbanavichene s.n. (LE; as Mannia fragrans var. inodora); Amurskaya Province, Bureinsky District, left side of Bureya River near Cheudga Settlement, 12 July 1973, D.I. Martynenko s.n. (VBGI, KPABG; as Mannia fragrans); *SAKHALIN Province, Kuril Islands, Schikotan Island, Bezymyannaya Bay near Nepokorniy Cape, $\sim 43^{\circ} 42^{\prime} \mathrm{N}, 146^{\circ} 38^{\prime} \mathrm{E}$, on wet rocks near stream, on wet fine-grained soil, 23 July 2010, V.Yu. Barkalov s.n. (VBGI, KPABG; as Reboulia hemisphaerica); PRIMORSKY TERRITORY, *Ol'ginskiy District, Vatovskogo Peninsula, northern edge of Vladimir Bay near Ol'ga Settlement, $43^{\circ} 53^{\prime} 00^{\prime \prime} \mathrm{N}, 131^{\circ} 30^{\prime} 37^{\prime \prime} \mathrm{E}, 25 \mathrm{~m}$ alt., finegrained ground in crevice of coastal cliff, 21 Sept. 2007, V.A. Bakalin \#P83-16-07 (VBGI, KPABG; as Reboulia hemisphaerica); Khankajsky District, Khankajsky State Reserve, Luzanovskaya Sopka cordon, 16 July 1997, S.K. Gambaryan s.n. (VBGI, KPABG; as Mannia fragrans); Ussurijsky District, neighborhood of Kamenushka Settlement, left side of Komarovka River Valley, 28 May 2008, V.A. Bakalin \#P-1-4-08 (VBGI, KPABG; 
as Athalamia nana (Shimizu \& S. Hatt.) S. Hatt. and Targionia hypophylla L.). *JAPAN, OHTAKI-MURA, Chichibu, Saitama Prefecture, $50^{\circ} 18^{\prime} \mathrm{N}, 130^{\circ} 28^{\prime} \mathrm{E}$, on wet fine-grained soil, with sporogonia, 6 July 1957, H. Inoue \#8086 (TNS 142061; as Mannia levigata Shimizu \& S. Hatt., ${ }^{2} 7$ July 1957, H. Inoue \#8084 \& 8085 (TNS 202602, 202603 as Mannia levigata).

SPECIMENS OF MANNIA CALIFORNICA EXAMINED: PAKISTAN, Northwest Frontier Province, Dunga Gali (North of Murree), 20 August 1990, M. Higuchi \#19773 (TNS; KPABG); ibidem, Kaghan Valley, Bajakot, 24 July 1990, M. Higuchi \# 20313 (TNS; KPABG); USA, Arizona, Santa Cruz County, Santa Rita Mts, Madera Canyon, 25 March 1995, W.B. Schofield \& R.M. Schuster \#B158559 (TNS).

ACKNOWLEDGMENTS. We are greatly indebted to the Curators of MHA (Dr. Michael Ignatov) and NICH (Dr. Masami Mitzutani) for specimen loans; Dr. Vyacheslav Barkalov (VLA) for providing us with collections of liverworts he gathered on Shikotan Island; Matvey Bakalin for preparing the line drawing; Dr. Nadezhda Konstantinova (KPABG), Dr. Alexey Potemkin (LE) and the anonymous reviewer for careful revision of the manuscript, valuable comments and suggestions; Hilary Wallace and Mike Procer for checking the English of the submitted manuscript; and Dr. Irina Sokolova (LE) for helping us write the taxonomic remarks on Mannia androgyna. This work was in part supported by the Russian Foundation for Basic Research (grants no. 12-04-01476, 13-04-00775) and the 'Research on the Earth's surface processes and biota in and near the Sea of Japan' program of the National Museum of Nature and Science, Tokyo.

\footnotetext{
2 Japanese specimens collected by H. Inoue (\#\#TNS 142061, 202602, 202603) near locus classicus of Mannia levigata Shimizu \& S. Hatt. and identified by him as M. levigata are characterized by: $(i)$ both paroicous and female-ventral autoicous inflorescences; (ii) pale grayish oil-bodies in both aerenchyma and basal tissue; and (iii) yellow-brown to straw-colored saccate spores (Fig. 2). Due to those features we re-identified them as $M$. androgyna. However, this does not mean that $M$. levigata is a synonym of $M$. androgyna. The former is characterized (unlike M. androgyna) by (i) a delicate, pale to deep green thallus; (ii) having plants not of xeric habit; (iii) dorsal epidermal cells almost invisible; (iv) having a single ventral scales appendage; and $(v)$ having spores distally areolate or ridged. It was discussed by Borovichev and Bakalin (2013a). Schill (2006: 124) regarded $M$. levigata as a synonym of $M$. californica; this is contrary to our previous observations discussed by Borovichev and Bakalin (2013a).
}

\section{REFERENCES}

ArNell S. 1961a. Hepatics collected in the Cape Verde Islands by Mr. Knut Byström. Bot. Not. 114(2): 176-180.

Arnell S. 1961b. List of the Hepaticae of the Canary Islands. Svensk Bot. Tidskr. 55(2): 379-393.

Borovichev E. A. \& BaKalin V. A. 2013a. Mannia levigata (Marchantiophyta: Aytoniaceae) - first record outside of Japan in the Russian Far East. Polish Bot. J. 58(1): 217-220.

Borovichev E. A. \& BaKalin V. A. 2013b. 13. Mannia androgyna (L.) A. Evans. In: L. Ellis, V. A. BAKAlin, E. Baisheva, H. Bednarek-Ochyra, R. Ochyra, E. A. Borovichev, S. S. Choi, B.-Y. Sun, P. Erzberger, V. E. Fedosov, R. Garilleti, B. Albertos, P. Górski, P. Hásková, N. G. Hodgetts, M. Ignatov, A. Koczur, L. E. Kurbatova, M. Lebouvier, A. Mežaka, J. Miravet, P. Pawlikowski, R. D. Porley, J. A. Rosselló, M. S. Sabovljević, J. Pantović, A. Sabovluević, W. Schröder, S. ŞTEFĂNUŢ, G. M. SuÁREZ, M. Schiavone, Ö. T. YayintaŞ \& J. VÁŇA 2013b. New national and regional bryophyte records, 36. J. Bryol. 35(3): 232.

Borovichev E. A. \& Nyporko S. A. 2014. Three taxa from Aytoniaceae family (Marchantiophyta), new for the Ukrainian liverwort flora. Ukrayins'k. Bot. Zhurn. 71(1): 66-70 (in Russian with English summary).

Borovichev E. A., Konstantinova N. A. \& Andrejeva E. N. 2012. The genus Sauteria Nees (Cleveaceae, Marschantiophyta) in Russia. Arctoa 20: 181-188.

Brotherus V. F. 1892. Enumeratio muscorum Caucasi. Hepaticae. Acta Soc. Sci. Fenn. 19(12): 141-161.

Casas C., Brugués M., Cros R., Sérgio C. \& Infante M. 2009. Handbook of liverworts and Hornworts of the Iberian Peninsula and the Balearic Islands. Institut d'Estudis Catalans, Barcelona.

Corda A. J. C. 1829. Genera Hepaticarum. Die Gattungen der Lebermoose. In P. M. OpIz (ed.), Beiträge zur Natürgeschichte 12. C. W. Enders, Prag. [Facsimile reprint]. Ann. Bryol. 10(1938): 9-15.

Evans A. 1938. The invalidity of the genus Grimaldia of Raddi. Chron. Bot. 4: 223-225.

Frahm J.-P. 2010. Mosses and Liverworts of the Mediterranean: an illustrated field guide. Books on Demand $\mathrm{GmbH}$, Norderstedt.

Frye T. C. \& Clark L. 1937. Hepaticae of North America. Univ. Wash. Publ. Biol. 6: 1-162.

Gottsche C. M., Lindenberg J. B. G. \& Nees von EsenBECK C. G. 1844-1847. Synopsis Hepaticarum. Meissner, Hamburg.

Gray S. F. 1821. A natural arrangement of British plants. Baldwin, Cradock and Joy, London.

Grolle R. 1968. Miscellanea hepaticologica 81-90. Transactions of the British Bryological Society 5: 541-547. 
Grolle R. 1975. Miscellenea hepaticologica 141-150. J. Bryol. 8: $483-492$.

Grolle R. 1981. Proposal to conserve Preissia Corda 1829 against Cyathophora S. Gray 1821 (Hepaticopsida). Taxon 30: 495-496.

Grolle R. 1983a. Nomina generica Hepaticarum; references, types \& synonyms. Acta Bot. Fenn. 121: 1-62.

Grolle R. 1983b. Proposals to conserve Mannia and Pellia (Hepaticopsida). Taxon 32: 135.

Grolle R. 1983c. Hepatics of Europe including the Azores: An annotated list of species, with synonyms from the recent literature. J. Bryol. 12: 403-459.

Hugonnot V. \& Schill D. B. 2006. Mannia californica (Gottsche ex Underw.) L. C. Wheeler (Aytoniacaea, Marchantiales) in Ardčche (France), new to Europe. Cryptog. Bryol. 27(1): 181-189.

Konstantinova N. A., Akatova T. V. \& Savchenko A. N. 2009. Hepatics of Caucasian State Nature Reserve (Northwest Caucasus, Russia). Arctoa 18: 121-134.

Kürschner H., Buck W. R. \& Sollman P. 2001. Two tropical species new to the bryophyte flora of the Arabian Peninsula: additions to the bryophyte flora of the Arabian Peninsula and Socotra 2. Nova Hedwigia 73(1/2): 253-259.

Leitgeb H. 1881. Untersuchungen über die Lebermoose. 2. Marchantieen. O. Deistung, Jena.

Long D. G. 2006. Revision of the genus Asterella P. Beauv. in Eurasia. Bryophyt. Biblioth. 63: 1-299.

Micheli P. A. 1729. Nova Plantarum Genera. Typis Bernardi Paperinii, Florentia.

MÜLLER K. 1954. Die Lebermoose Europas. In: Rabenhorst's Kryptogamenflora von Deutschland, Österreich und der Schweiz. 3. Auflage. 6(1): 1-756. Akademische Verlagsgesellschaft Geest \& Portig K.-G., Leipzig.

Perold S. M. 1994. Studies in the Marchantiales (Hepaticae) from Southern Africa. 4. Mannia capensis, section and subgenus Xeromannia (Aytoniaceae). Bothalia 24: 9-14.

RADDI G. 1818. Ex cryptogamia stirpium. In agro Florentino collectarum. Dacades Duae. Opusc. Sci. 2: 349-361.

SChiffner V. 1893. Hepaticae. In: A. Engler \& K. Prantl (eds), Die natürlichen Pflanzenfamilien. 1(3): 3-141. W. Engelmann, Leipzig.

SCHIFFNER V. 1908. Morphologische und biologische untersuchungen über die Gattungen Grimaldia und Neesiella. Hedwigia 47: 306-320.
SCHILl D. 2006. Phylogeny taxonomy and phylogeny of the liverwort genus Mannia (Aytoniaceae, Marchantiales). PhD Thesis, University of Edinburgh, Edinburgh. https:// www.era.lib.ed.ac.uk/handle/1842/7463.

Schill D. B., Long D. G. \& Köckinger H. 2008. Taxonomy of Mannia controversa (Marchantiidae, Aytoniaceae), including a new subspecies from East Asia. Edinburgh $J$. Bot. 65(1): 35-47.

Schrank F. P. 1805. Catalogus Plantarum Horti Academici Landishutani. http://reader.digitale-sammlungen.de/ resolve/display/bsb10229512.html.

Schumacker R. \& VÁŇA J. 2005. Identification keys to the liverworts and hornworts of Europe and Macaronesia (distribution and status). $2^{\text {nd }}$ edition fully revised and updated. Sorus, Poznań.

SCHuster R. M. 1953. Boreal Hepaticae, a manual of the liverworts of Minnesota and adjacent regions. Amer. Midl. Naturalist 49(2): 559-612.

Schuster R. M. 1992. The Hepaticae and Anthocerotae of North America. 6. Field Museum of Natural History, Chicago.

Scopoli J. A. 1772. Flora Carniolica. 2. Editio secunda. I. P. Krauss, Vindobonae.

Singh S. K. \& Singh D. K. 2009. Hepaticae and Anthocerotae of Great Himalayan National Park (HP), India. Botanical Survey of India, Kolkata.

SöDerström L., Urmi E. \& VÁŇa J. 2002. Distribution of Hepaticae and Anthocerotae in Europe and Macaronesia. Lindbergia 27: 3-47.

Stephani F. 1898-1924. Species Hepaticarum. 6. Supplementum ad Vol. 1-5. Publication de 1'Institut Botanique et Herbier Boissier, Genève.

UdAR R. \& Chandra V. 1965. Two new species of Mannia, $M$. foreaui Udar et Chandra and $M$. perssonii Udar et Chandra, with a note on the genus and its Indian species. Canad. J. Bot.. 43: 147-160.

WheELER L. C. 1934. The genus Grimaldia. Bryologist 37: 87-88.

Wigginton M. J. 2004. Checklist and distribution of the liverworts and hornworts of sub-Saharan Africa, including the East African Islands (edition 2, 09/04). Tropical Bryology Research Reports 5: 1-102.

ZilJSTRA G. 1989. Progress in nomina conservanda et rejicienda. Bryol. Times 51: 7-8.

ZILJSTRA G. 1990. Report of the committee for Bryophyta I. Taxon 39: 289-292. 